\title{
Aquifer system and groundwater potency in coastal area of Kretek, Bantul Regency, Indonesia
}

\author{
La Ode Saleh Isa ${ }^{1)}$ \& Ignasius Loyola Setyawan Purnama ${ }^{1)}$ \\ ${ }^{1)}$ Faculty of Geography, Universitas Gadjah Mada, Yogyakarta, Indonesia
}

\begin{abstract}
The existence of groundwater in coastal areas really needs attention because of its vulnerability to sea water intrusion. Utilization and good management are needed to maintain its sustainability. The purpose of this research is to determine the aquifer system in the study area and to calculate the groundwater potency. The aquifer system is determined by processing geoelectric sounding data using Rockworks 16 software. Groundwater potency is calculated using a static approach. The safe yield of groundwater is calculated by multiplying of groundwater fluctuation, village area and the specific yield. Water requirement is calculated base on domestic, livestock and tourism water requirement. The results showed that the Kretek District had two aquifer units, namely the fluvio marin plains and sand dunes. In the fluvio marin plains, most of the constituent material is sand with clay as inserts, while in the aquifer unit the sand dune has constituent material in the form of unconsolidated sand originating from the Merapi Volcano. The groundwater potency of the study area is $234,448,0000 \mathrm{~m}^{3} /$ year and the safe yield is $11,772,400 \mathrm{~m}^{3} /$ year. With the water requirement for domestic, livestock and tourism are $555,044 \mathrm{~m}^{3} /$ year, the groundwater potency in the study area is still sufficient. However, it is recommended that the well drilling does not exceed a depth of 40 meters, because at several locations there has been detected an interface. In addition, in several locations there were also detected connate water originating from ancient marines during the deposition process of the fluvio marin plains in the past.
\end{abstract}

Keywords: aquifer, groundwater, coastal area, Kretek District, Bantul Regency

\section{Introduction}

In accordance with the concept of the hydrological cycle, the amount of water on earth is constant [1-2]. Lack and excess of water in a place is actually just a matter of uneven distribution, either according to space or time, or because of its unbalanced form (solid, liquid, gas).

According to [3-4], along with the advancement of civilization, human needs in various aspects are increasing, including the requirement of water sources. Currently, there are more and more problems related to the need for and supply of water resources [5-6]. The thing expected is the existence of water resources that are sufficient in number, of good quality and evenly distributed in space and time. Therefore, in water resource management, what must always be strived for is efforts to make water available where it is needed with good and sustainable quality [7].

Groundwater is one part of natural resources whose existence is very much needed by humans, because until now the majority of the population's daily water sources are still sourced from groundwater [8-9]. However, the availability of groundwater is not always the same from one place to another, likewise its utilization is not the same.

Groundwater is found in various geological formations, especially in aquifers [10-11]. Aquifers are rock formations that can store and transmit water. In general, aquifers cover a large area and can be seen as underground water reservoirs. The water that enters this reservoir is either natural or artificial, and flows out by gravity or through artificial wells. The annual volume of water entering and leaving is only a small part of the total storage capacity.
The usage of groundwater resources for various purposes must pay attention to the total water contained in a groundwater basin. By considering a basin as a natural underground reservoir, the use of groundwater in one place will certainly also affect the overall groundwater contained in the basin. Therefore, the concept of equilibrium between the amount of water entering and leaving a basin must be considered in the utilization of groundwater.

The safe yield of a groundwater basin is the amount of water that can be taken from the groundwater basin without causing unwanted effects. Therefore, to preserve groundwater, groundwater extraction must be limited to safe yield [12-13].

Kretek District is one of the districts in Bantul Regency which has a coastal area. Geomorphologically, the area is located in the fluviomarine plains of Merapi Volcano and sand dunes. Due to the existence of Parangtritis tourism object, this area is growing rapidly with a relatively dense population than the surrounding area. As a result, the water requirement for daily needs also increases, most of which comes from groundwater. This research focuses on Tirtohargo and Parangtritis Village which are the coastal areas of this district (Figure 1). 


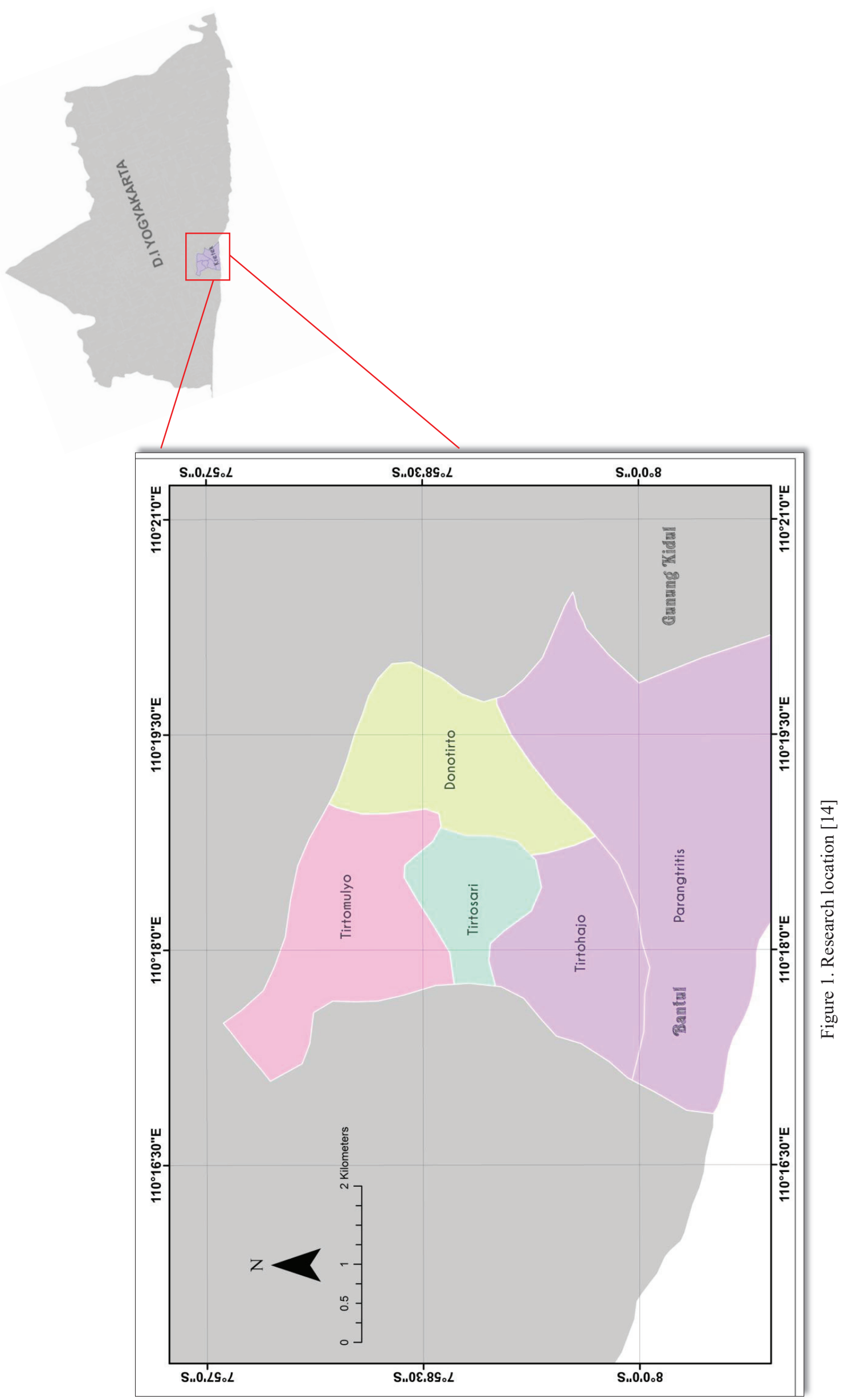




\section{Method of research}

\subsection{Calculation of water availability}

The results of geoelectric data processing on field sounding resulted in several subsurface lithology layers. To make it easier to delineate the groundwater aquifer layer at the study site, further data processing was carried out by using 3D modeling and 2D cross section of the prediction point using Rockworks 16 software.

\subsection{Calculation of groundwater potency and its safe yield}

Groundwater potency is calculated using a static approach :

$$
\text { Vat }=\text { Sy x Vak }
$$

where Vat is groundwater volume that can be extracted from the aquifer, Sy is specific yield and Vak is aquifer volume, obtained by multiplying between village area and aquifer thickness. The safe yield of groundwater is calculated by multiplication of groundwater fluctuation, village area and the specific yield.

$$
\text { Safe yield }=\text { F. A. Sy }
$$

where $\mathrm{F}$ is the groundwater fluctuation and $\mathrm{A}$ is village area.

\subsection{Calculation of water requirement}

Water requirement is calculated base on domestic, livestock and tourism water requirements. The water requirement for domestic is determined according to the number of the population and the amount of water demand of each person/day. Due to the research area is a village with a fairly dense population, the water requirement of 100 liters/person/day is determined.

Water requirement for livestock is calculated based on the number of livestock and water consumption of each livestock/day. The standard of water requirement for big livestock (cow, buffalo, horse) is 40 liters/livestock/day; small livestock (goat, sheep) is 5 liters/livestock/day; and poultry is 0.6 liter/livestock/day [15].

\section{Result and discussion}

\subsection{Aquifer system of the research area}

Kretek district has two aquifer units, i.e. the fluvio marin plains and sand dunes. In the fluvio marin plains, most of the constituent material is sand with clay as inserts. The bedrock that underlies this aquifer system is limestone and marl of the Sentolo Formation.

According to MacDonald and Partners (1984), the Fluvio Marin Plains Aquifer unit is a major aquifer, which is a highly capable aquifer to provide adequate water for domestic and industrial purposes. Observing the characteristics of the aquifer, the aquifer permeability is classified in the fast criteria reaching $59.9 \mathrm{~m} /$ day, while the transmissibility of the aquifer and pescific discharge reaches $921.9 \mathrm{~m}^{2} /$ day and 4.00 $\mathrm{m}^{3} / \mathrm{sec} / \mathrm{m}$.

Sand dune aquifer units are located along the coast of the study area. The width of this aquifer ranges from 3 to $4 \mathrm{~km}$, with the constituent material in the form of unconsolidated sand originating from Merapi Volcano. The material is carried out to sea by the Opak River and thrown back on land by the wave and wind.

This aquifer has a thickness between 20 - 45 meters. The further north the thickness decreases to form a wedge structure, with the base of the aquifer in the form of clay from marine deposits. Above the surface, this aquifer system is characterized by alternating between beach ridge and swales. The material in the swale is relatively smoother than the beach ridge.

Referring to the results of the electrical sounding carried out by [17-18], in more detail the research area can be made a 3D model as shown in Figure 2.

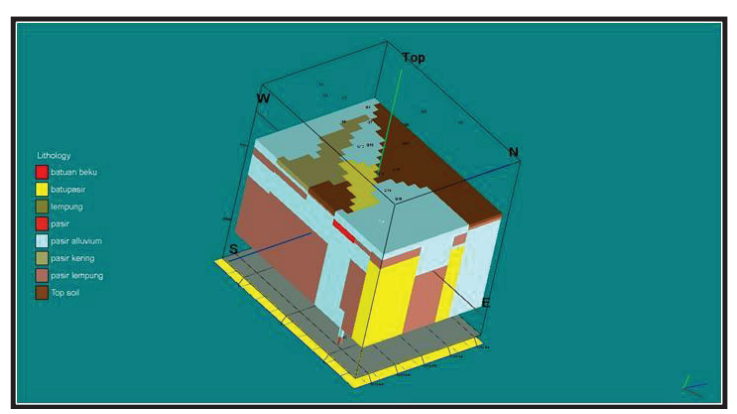

Figure 2. 3D lithology profile of the research location

In Figure 2, it can be seen that there are variations in subsurface lithology at each geoelectric sounding point. Clay and alluvium sand materials dominate the research area. Clay sand material becomes aquitard in this area, while alluvium sand material becomes the main aquifer constituent rock. In general, the aquifer system in the study area is divided into two formations, namely the fluvio marin plains and the sand dune. The fluvio marin plains is grouped into two facies, namely coastal sediment and river sediment. Beach sediment is composed of clay, sand, and gravel material, while river sediment is composed of clay, silt and fine sand, so that clay and alluvium sand materials are almost scattered in all research locations. Sand dune is composed of fine sand and coarse sand which is a manifestation of the marin and aeolin processes, so that alluvium sand material is also present in these landforms. Further explanation will be discussed in each cross section.

Cross section $\mathrm{A}-\mathrm{A}^{\prime}$ has a direction from north to south and is composed of variations in the subsurface lithology layer (Figure 3). Alluvium sand material dominates this cross section with different layer thicknesses. This material becomes the groundwater aquifer at the research location. The best groundwater potential is found at points G9, G5, and G8 because they have a fairly thick layer. However, at point G8 there is connate water at a depth of $20-30 \mathrm{~m}$ and below that depth the alluvium sand layer is saturated with groundwater again. Connate water at point G8 is salt water originating from marines during the past deposition of fluvio marin plains. Clay sand saturated with groundwater is found at points G12, G14, and G15 with varying thicknesses. Furthermore, igneous 
rock was inserted at point G14. This material is thought to be a lava flow from Mount Merapi.

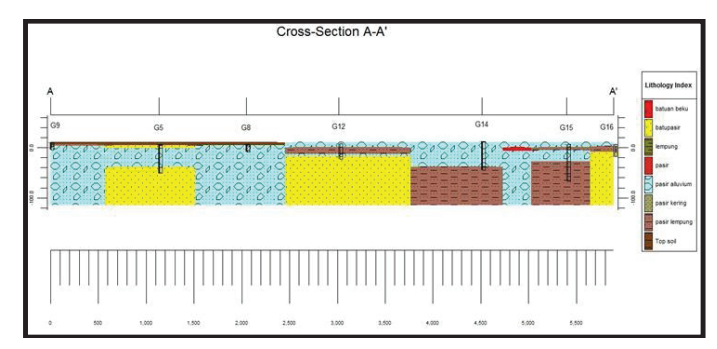

Figure 3. Cross section $\mathrm{A}-\mathrm{A}$ '

In cross section $\mathrm{B}-\mathrm{B}$ ', there are several layers of subsurface lithology (Figure 4). Alluvium sand beds are present at all measurement points and become groundwater aquifers at the study sites with varying layer thicknesses. However, at point G8, there is connate water in the alluvium sand material, which originated from the marines during the deposition process of the fluviomarin plains in the past. Below this point, the alluvium sand layer is again saturated with groundwater. Clay sand layers are also present at almost all measurement points with varying layers. At point $\mathrm{G} 2$, there is an interface between the groundwater and saltwater zones at a depth of $40.4-64.7 \mathrm{~m}$. In addition, at depths below $64.7 \mathrm{~m}$, there is a layer of clay sand in salty conditions. This phenomenon is caused by the sounding point which is in the beach ridge. For points G3 and G4, clay sand is saturated with groundwater. When viewed from the lithological layer, the research locations at these points have high groundwater potential.

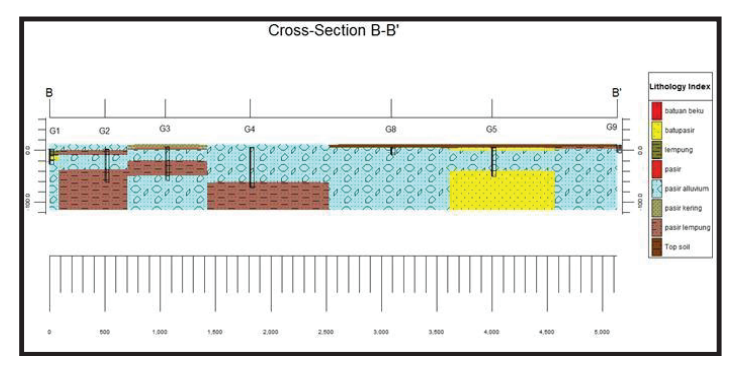

Figure 4. Cross section B - B'
In the $\mathrm{C}-\mathrm{C}^{\prime}$ cross section, alluvium sand material which is saturated with groundwater is found at all sounding points with different layer thicknesses (Figure 5). This material is groundwater aquifer at the research location. At the sounding point G8 with depth of $2.66-11.6 \mathrm{~m}$, alluvium sand is saturated with groundwater containing connate water originating from marines during the past deposition of the fluvio marin plain. However, below $11.6 \mathrm{~m}$, the alluvium sand is saturated with groundwater again. Clay sand material at points G6 and G7 also contains saturated groundwater, but at point G6 there is brackish water at a depth of more than $100 \mathrm{~m}$. The brackish water at this depth is caused by the interface between groundwater and sea water because the position of the G6 measurement point is in the beach ridge. When viewed from the lithological layer, the research locations at these points have high groundwater potential.

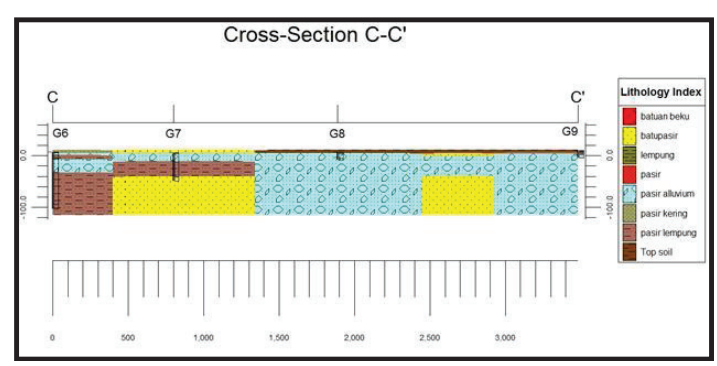

Figure 5. Cross section $\mathrm{C}-\mathrm{C}$ '

\subsection{Groundwater potency}

As described in the research method, groundwater potency in the study area is determined based on the groundwater potency in each district, by multiplying of the thickness of the aquifer, the specific yield, and the area of each district. The safe yied of groundwater extraction is the result of the multiplication of the area, the specific yield and the fluctuation of groundwater. The results of the calculation of these two parameters are shown in Table 1.

Table 1. Groundwater potency in each district

\begin{tabular}{|l|c|c|c|c|c|c|c|}
\hline No. & Village & Area $\left(\mathrm{m}^{2}\right)$ & $\begin{array}{c}\text { Sy } \\
(\%)\end{array}$ & $\begin{array}{c}\text { Aquifer } \\
\text { Thickness }(\mathrm{m})\end{array}$ & $\begin{array}{c}\text { Groundwater } \\
\text { Fluctuation }(\mathrm{m})\end{array}$ & $\begin{array}{c}\text { Groundwater } \\
\text { Potency }\left(\mathrm{m}^{3} / \text { year }\right)\end{array}$ & $\begin{array}{c}\text { Safe Yield } \\
\left(\mathrm{m}^{3} / \text { year }\right)\end{array}$ \\
\hline 1. & Tirtohargo & $3,620,000$ & 38 & 40 & 2 & $55,024,000$ & $2,751,200$ \\
\hline 2. & Parangtritis & $11,870.000$ & 38 & 40 & 2 & $180,424,000$ & $9,021,200$ \\
\hline
\end{tabular}

Source : Kretek District in Number 2020 and calculation result

Based on the results of the calculations in Table 1, it can be seen that the research area has the groundwater potency $235,448,000 \mathrm{~m}^{3} /$ year, with the safe yield of the groundwater extraction $11,772,400$ $\mathrm{m}^{3} /$ year. Parangtritis Village has higher groundwater potency and safe yields than Tirtohargo Village.

\subsection{Water requirement}

The amount of water needed for domestic requirement in the study area is 1,091,000 liters/day. Tirtohargo Village has a domestic water requirement of 303,300 liters/day and Parangtritis District has a domestic water requirement of 787,700 liters/day (Table 2). 
The requirement for water for livestock in the study area is 63,062 liters/day. In Tirtohargo Village the water requirement is 24,825 liters/day, while in Parangtritis Villlage is 38,237 liters/day.

Table 2. The water requirement of domestic and livestock in the study area in 2019

\begin{tabular}{|c|l|c|r|c|c|c|c|}
\hline \multirow{2}{*}{ No. } & \multirow{2}{*}{ Village } & \multicolumn{2}{|c|}{ Domestic } & \multicolumn{4}{c|}{ Livestock } \\
\cline { 3 - 8 } & $\begin{array}{c}\text { Population } \\
\text { (person) }\end{array}$ & $\begin{array}{c}\text { Water Requirement } \\
\text { (liters/day) }\end{array}$ & Big & Small & Poultry & $\begin{array}{c}\text { Water Requirement } \\
\text { (liters/day) }\end{array}$ \\
\hline 1. & Tirtohargo & 3033 & 303,300 & 554 & 0 & 4441 & 24,825 \\
\hline 2. & Parangtritis & 7877 & 787,700 & 860 & 0 & 6396 & 38,237 \\
\hline
\end{tabular}

Source : Kretek District in Figure 2020 dan calculation result

\subsection{Evaluation of groundwater potency and safe yield}

The results of the calculation show that the amount of water requirement in the study area is $421,233 \mathrm{~m}^{3} /$ year, while the safe yield of groundwater extraction are $11,772,400 \mathrm{~m}^{3} /$ year. Based on this data, it can be said that the groundwater extraction that has been carried out by residents has not exceeded the safe yield. However, it should be noted that both village are tourist areas. Based on the data, tourist visits in this area are around 1,338,112 people per year, so if the number of tourists is also taken into account, the additional water requirement added by $133,811 \mathrm{~m}^{3} /$ year to $555,044 \mathrm{~m}^{3} /$ year.

However, it is recommended that the well drilling does not exceed a depth of 40 meters, because at point $\mathrm{G} 2$, there is an interface in a depth of $40.4-64.7 \mathrm{~m}$. Beside that, in G6 there is brackish water at a depth of more than $100 \mathrm{~m}$. In several locations there were also detected connate water originating from ancient marines during the deposition process of the fluvio marin plains in the past. For example at point G8 there is connate water in a depth of $20-30 \mathrm{~m}$

\section{Conclusion}

1. Kretek district has two aquifer units, i.e. the fluvio marin plains and sand dunes. In the fluvio marin plains, most of the constituent material is sand with clay as inserts. The bedrock that underlies this aquifer system is limestone and marl of the Sentolo Formation. Sand dune aquifer units are located along the coast of the study area. The width of this aquifer ranges from 3 to $4 \mathrm{~km}$, with the constituent material in the form of unconsolidated sand originating from Merapi Volcano.

2. The groundwater potency in the study area is $234,448,0000 \mathrm{~m}^{3} /$ year and the safe yield is $11,772,400 \mathrm{~m}^{3} /$ year. With the water requirement for livestock and tourism of $555,044 \mathrm{~m}^{3} /$ year, the groundwater potency in the study area is still sufficient. However, it is recommended that the well drilling does not exceed a depth of 40 meters, because at several locations has been detected an interface. In addition, in several locations there were also detected connate water originating from ancient marines during the deposition process of the fluvio marin plains in the past.

\section{Acknowledgement}

This article is result of a study financed by the Final Assignment Recognition (Rekognisi Tugas Akhir/RTA) Programme Universitas Gadjah Mada Fiscal Year 2021.

\section{Reference}

1. Davie, T. Routledge, Taylor \& Francis Group (2008).

2. Purnama I L S. Indonesian Journal of Geography 40 (2) : 153-166 (2008).

3. Senanayake I P., Dissanayake D M D O K., Mayadunna B B \& Weerasekera W L. Geoscience Frontiers 7 (2016) : 115-124 (2016).

4. Belkhiri L., Tiri A \& Mouni L. Groundwater for Sustainable Development 11 (2020) 100473 (2020).

5. Yangxiao Zhou \& Wenpeng Li. Geoscience Frontiers 2(2) (2011) 205e214 (2011).

6. Rahmawati, N., Vullaume, J.F., Purnama, S. Journal of Hydrology 494 (2013) : 146-159 (2013).

7. Purnama, I L S. Indonesian Journal of Geography, 51(2), 206-216 (2019).

8. Messene G M. Journal of Environment and Earth Science Vol.7, No.2, 2017 : 32-39 (2017).

9. Purnama, I L S and Cahyadi A. Taiwan Water Conservancy 67 (4) : 57-67 (2019).

10. Todd, D.K., Mays, L.W. John Wiley \& Sons, New York (2005).

11. Purnama I L S. 2010. Hidrologi Air Tanah. Penerbit Kanisius.

12. Sophocleous M. Natural Resources Research, Vol. 9, No. 2, $2000:$ 99-110. (2000).

13. Purnama I L S., Marfai, M.A. Journal of Natural Resources and Development. 2012 (02) : 25-32 (2012).

14. Statistik Center Bureau of Bantul Regency. Kretek Distrik in Figures 2020.

15. Departemen Pekerjaan Umum. Proyek Pembinaan Pengelolaan Sumberdaya Air, Direktorat Pendayagunaan Sumberdaya Air, Direktorat Jenderal Pengairan, Departemen Pekerjaan Umum, Jakarta (1997). 
16. MacDonald \& Partners. Directorate General of Water Development. Groundwater Development Project (P2AT) Indonesia (1984).
17. Putri F W. Thesis. Fakultas Geografi UGM (2008).

18. Kurniadhini F. 2016. Skripsi. Fakultas Geografi UGM (2016). 